\title{
SLAV CULTURAL MEMORY, NOSTALGIA AND HUMOUR IN THE OEUVRE OF DANILA VASSILIEFF (1897-1958), RUSSIAN ÉMIGRÉ ARTIST IN AUSTRALIA
}

\author{
Zoja Bojić \\ Institute for Literature and Arts \\ Belgrade, Serbia
}

Key Words: Danila Vassilieff, Australian art, Slav and Russian cultural memory, nostalgia, humour

Summary: Danila Vassilieff (1897 -1958) was a Russian émigré artist who lived and worked in Australia. By far the largest and most significant part of his painterly and sculptural oeuvre Vassilieff executed on Australian soil, in the states of New South Wales and Victoria.

This article explores Vassilieff's visual arts ideas and idiom created within the parameters of his Russian and Slav cultural memory and characterised by his émigré experience. It argues that Vassilieff's art was fully formed only after the artist's experiencing an existence of a permanent émigré in Australia and that both his ideas and his idiom flourished in opposition to the cultural traditions of his new environment.

Vassilieff's relationship with his Russian and Slav cultural heritage was traced in the monograph Imaginary homelands, the art of Danila Vassilieff (Bojic 2007). This essay complements the extant research by examining Vassilieff's relationship with his Australian environment as reflected in his work.

Vassilieff's experience of a permanent émigré formed his visual arts idiom and provided for the large pool of themes and topics in his work. Much of his oeuvre bridged the varied cultural traditions of his Russian homeland and the hardship he experienced living in a barren Australian land. There were two reasons for this. One was the artist's position of being an émigré; the other was that of being an artist. His initial alone-ness in a new Australian environment allowed for his one-ness and thus contributed to the uniqueness of his expression and his oeuvre, recognised as such later on by his Australian peers.

The chronic trauma of being a permanent émigré was a continual feature of Vassilieff's life and of his work. His deep feelings of nostalgia were an essential quality of his existence in exile. The artist himself would attempt to counterbalance 
this with his all-pervasive energetic good will and his refined sense of humour and sweet irony on occasions leading into a sarcasm, evident in many of his works.

\section{СЛОВЕНСКА КУЛТУРНА МЕМОРИЈА, НОСТАЛГИЈА И ХУМОР \\ У ДЕЛУ ДАНИЛЕ ВАСИЉЕВА (1897-1958), РУСКОГ ЕМИГРЕ УМЕТНИКА У АУСТРАЛИЈИ}

Кључне речи: Данила Васиљев, словенска и руска културна меморија, носталгија, хумор

Апстракт: Данила Васиљев (1897-1958) је руски емигре уметник који је живео и радио у Аустралији, у државама Нови Јужни Велс и Викторија, где је створио највећи део свог опуса.

Овај есеј истражује идеје Данила Васиљева и његов ликовни уметнички идиом. Уметникове идеје потичу из традиција његове руске и словенске културне меморије и у директној су вези са његовим емигре искуством. Уметност Даниле Васиљева у потпуности је формирана тек после његовог трајног досељења у Аустралију где су се његове идеје и идиом оформиле наспрам и у супротности са културним традицијама његовог новог окружења.

Монографија Imaginary homelands, the art of Danila Vassilieff (Вojic 2007) исцрпно је истражила уметников однос према свом руском и словенском културном наслеђу. Овај есеј надовезује се на то истраживање и употпуњује га тиме што разматра однос овог уметника према његовом аустралијском окружењу. Тај однос је одражен у његовим многим ликовним делима и целокупном опусу.

Уметников опус показује да је Васиљев остао емигрант током више од двадесет година живота и рада у Аустралији. Признање за живота није добио, а аустралијски уметници су тек касније разумели његово дело. Два су кључна разлога за велике тешкоће са којима су се уметник и његово дело суочавали у Аустралији. Један је тај што је Васиљев био емигрант, други то што је био уметник у средини која није била довољно отворена ни за емигранте ни за уметнике. То искуство неприпадања његовој новој заједници један је од узрока неких од константих тема и мотива у уметниковом стваралаштву, чије је порекло у руским и словенским традицијама његове домовине. Истовремено, то искуство је обликовало и његов ликовни уметнички идиом. Уметникова усамљеност коју је осећао од првих дана у тој новој средини истовремено је и извор његове јединствености и јединствености његовог опуса.

Трајна особина живота и дела Даниле Васиљева била је хронична траума што је у својој средини остао вечити емигрант. Суштинска особина уметниковог живота и дела у егзилу било је његово дубоко осећање носталгије које је покушавао да ублажи својом енергијом и рафинираним смислом за хумор и иронију. 
The 'father of Australian modernism' Russian artist Danila Vassilieff, a figurative expressionist painter and sculptor, migrated to Australia with intention to settle there, twice. Once, in 1923, in the aftermath of the Russian revolution in which he fought bloody battles against the Red Army, undertaking a dangerous and lengthy travel across Mongolia and various other regions of Asia and finally arriving in Australia via Shanghai. Vassilieff settled in the warm state of Queensland as a sugar cane cutter and railroad builder. Several years later, in 1929, he left Australia to pursue studies of art. The second time Vassilieff arrived in Australia in 1936 and for good as an accomplished modernist artist. He first lived in Sydney, then since 1937 in Melbourne and the State of Victoria. Between his leaving Australia in 1929 and returning there in 1936 Vassilieff lived and exhibited in Paris, Rio de Janeiro, West Indies, some other countries of South America, England, Spain and Portugal.

Vassilieff's work as a professional artist began in Brazil. He arrived in Rio de Janeiro in 1930 after briefly visiting Paris then spending many months at sea. In Rio he began attending art classes. Of all the art schools in Paris and in Rio or anywhere in between that he could have attended Vassilieff selected art classes conducted by a Russian émigré icon painter living in Rio at the time, Dimitri Ismailovich. Vassilieff continued attending Ismailovich's iconpainting classes also in 1931. At the time, Ismailovich was not a well-known artist and his icon painting skills were not in much demand. Only later he went on to obtain acknowledgment and a standing within the Brazilian arts scene (Bojic 30).

Three years after arriving in the region, in 1933, Vassilieff held solo exhibitions in Georgetown, Trinidad, Haiti, Santo Domingo, Puerto Rico, Jamaica and Martinique. His works of the time surviving either as originals or in copy were all executed in modernist expressionistic idiom and showed little trace of his icon-painting training. It can only be assumed that Vassilieff's accomplished modernist idiom was largely due to his being familiar with the art practices of Brazilian modernist painters during his time in Rio (Bojic 30, 31). However, during his early youth spent in Sankt Petersburg, Russia, Vassilieff would have become familiar with the ideology of the Russian art group Mir iskusstva, World of Art, with the early neoprimitivist work by the Russian artists Natalia Goncharova and Mikhail Larionov, as well as with the then current art practices of European modernists through their works acquired for some of the Russian grand collections of modern art (Bojic 2007: 28, 29).

In 1933 Vassilieff left Latin America for London. He lived there over the next two years, visited Spain and Portugal and exhibited there. In London, 
Vassilieff was introduced to the work of several modernist artists, especially of those directly and indirectly involved in the various productions of the Russian ballet ensembles in Europe such as the work of Vladimir Polunin, the chief London scene painter for Diagilieff's Ballets Russes (Bojic 2007: 33). In Spain and Portugal such encounters were not documented. However, he was very well aware of many aspects of modernist, and other, art practices there, especially importantly the works of El Greco in Toledo and elsewhere.

Upon arriving in Australia for the second time in 1936, Vassilieff started working and exhibiting as a professional artist. Over the period of the next twenty-three years in Australia, Vassilieff produced a large number of paintings and a body of sculpture introducing to the foreign shores his unique visual arts language imbued in his Russian and broader Slav cultural memory, and characterised by his émigré experience and nostalgia. Australia was and during Vassilieff's lifetime remained a foreign and comparatively isolated place with little contact with his culture of origin. Vassilieff could never return to his homeland. His sense of nostalgia defined him as an émigré in continual opposition to his new environment. Indeed it was only in Australia that nostalgia could be acknowledged and accepted as a construct evident in his work. In turn, it inspired much of the artist's Australian oeuvre.

\section{Nostalgia}

Shortly after Vassilieff's settling in Australia for the second time, over the period of several years between 1936 and 1940 the Colonel de Basil's Russian Ballet ensemble held over six hundred performances across Australia's major cities. The tours had a strong impact on the audiences and far fetching consequences in the development of dance schools. They provided inspiration for some Australian visual artists such as the young Sidney Nolan who was commissioned to create the sets for one of the productions. ${ }^{1}$ They also contributed to the evolution of the overall stage and performing arts culture in Australia (Carrol 2011). Vassilieff's experiencing the ensemble's artistic rendition of Russian and other myths in both Sydney and Melbourne inspired a new body of his work in the late 1930s and the early 1940s. His oeuvre was now to include his personal expressionistically rendered interpretations of his Russian Ballet theatre experiences, as well as other representations of characters from the artist's personal and cultural mythology. Those include the Russian wonder tales such as the Firebird and

\footnotetext{
${ }^{1}$ Serge Lifar's revised production of Icare, for the Melbourne tour of 1939-1940
} 
those from the stage production of the fable of Peter and the Wolf. Vassilieff can be single-handily credited for introducing to Australian art renditions of several key constructs. These are the constructs of myth, of Christian legends, of history as myth, of folklore, of a hero and anti-hero, of the forces of evil, of the forces of nature, and the construct of pure anima (Bojic 2007).

The artist's nostalgia is especially evident in his work at the challenging times of the WWII. Several paintings at the time are a testimony to his concern for his Russian homeland. His knowing that he could not return to his homeland spurred him to visualise it, as demonstrated by the painting Stalingrad executed in Australia in $1945 .^{2}$ REPRODUCTION 1 Inspired by the news from the war front of the long and exhausting battle for Stalingrad, it depicts a wheat field of his homeland within which the soldiers are dispersed. ${ }^{3}$ Soon after the war ended Vassilieff began making stone sculpture and until mid-1950s created many such works. Among them perhaps the most prominent were those directly inspired by his Russian cultural memory the values of which he was hopelessly attempting to transmit to his audiences. They include the works Flying horse (1951), ${ }^{4}$ REPRODUCTION 2 Gnome $(1950)^{5}$ REPRODUCTION 3 and Stenka Razin (1953). ${ }^{6}$ REPRODUCTION 4 Due to their subject matter more than their execution, most of these works did not and could not resonate with Vassilieff's Australian contemporaries.

Vassilieff's work is defined by the two interconnected constructs, the one of his cultural memory and the other of his relationship with his new environment. The artist's cultural memory emerges as a strong force in his work, possibly even more so in opposition to his daily experiences. Vassilieff's Russian and Slav cultural memory, although visible in his earlier works, especially those from Brazil, did not present itself as a dominant force at early stages of his career as a professional artist. Instead, it built up to form the artist's refuge from the world around him. The construct of cultural memory is not always to be equated with the one of nostalgia. In Vassilieff's oeuvre, nostalgia was clearly extending beyond his feelings for his own homeland. Instead, the artist's nostalgia also encompassed his past temporary homelands such as Brazil as demonstrated by a boisterous and happy painting

\footnotetext{
${ }^{2}$ Oil on canvas mounted on board, $49 \times 54 \mathrm{~cm}$, private collection

${ }^{3}$ In the early 1940s Vassilieff, who at the time of the Russian Revolution over two decades earlier fought against the Red Army, decided to join Australian Communist party in a gesture of support for the Soviet forces defending his homeland. However, disappointed by his new comrades Vassilieff quickly withdrew his membership.

${ }^{4}$ Lilydale marble, $39.5 \times 39.5$ x $20 \mathrm{~cm}$, Baillieu Myer collection

${ }^{5}$ Lilydale marble, $27.5 \times 15.2 \times 14 \mathrm{~cm}$

${ }^{6}$ Lilydale marble, 57 x 40 x $13.5 \mathrm{~cm}$, National Gallery of Australia, Canberra
} 
titled Rio he created in Australia in 1951, some thirty years after he left the city and the Brazilian shores.

In the early 1940s, Vassilieff began building his own home in the bush, in the area of Warrandyte, near Koorong where he was teaching art in the Koornong Experimental School. He would bring the rocks from a local quarry and use them as the principal building material. He named his house Stonygrad, meaning both the capital city and a stone construction. The house is now heritage listed, still sitting in the intact environment of vast Australian bush. Vassilieff grew vegetables and flowers on his property and kept chicken. His isolation there was complete. From time to time various folk from Melbourne including several young artists would visit him. Among them were the painters Ambrose Hallen, Albert Tucker and Joy Hester who were the subject of a group portrait painted by Vassilieff in 1942 - in turn, Tucker took numerous photos of Vassilieff, Stonygrad and the other visiting artists. Some accounts also mention several days long parties held there. Nevertheless, even Vassillieff's house, decorated in a manner that invoked various Russian traditions, was an émigré entity.

A significant segment of Vassilieff's painterly oeuvre thematically focuses on representations of urban scenes. Many are quick notations of places he visited during his various travels prior to settling in Australia for the second time. A large number of them were expressionistic paintings of street scenes from Sydney in 1936 and 1937, especially from the then industrial suburb of Surry Hills, and from Melbourne, especially from the suburb of Fitzroy, in the late 1930s and beyond. Living in Stonygrad in the 1940s and the early 1950s, Vassilieff painted profusely and extended his work to sculpture. Many of these works directly reference the artist's cultural memory and nostalgia such as the already mentioned sculptures Flying horse (a representation of Konek Gorbunok), Gnome (Karlik), or Stenka Razin.

Although gradual, the shift in Vassilieff's art in Australia from recording the everyday urban life of Sydney and Melbourne towards his introduction of personalised themes based on exclusively Russian cultural memory was enormous. Vassilieff's works depicting Sydney and Melbourne city scenes addressed his Australian audiences. Vassilieff's works representing the key characters of his Russian cultural memory did not and could not communicate with his Australian peers. There is little doubt that Vassilieff was aware of this.

The case in point is the imagery of a Joe Deuter. In 1942 while still building Stonygrad and living there, Vassilieff painted one of his 
masterpieces. It is the work titled Joe Deuter ${ }^{7}$ REPRODUCTION 5 which replicates the iconography of the popular icon of Prophet Ilia in the fire cart. The figure of Saint Ilia is replaced with the figure of a local peasant, and the fire chariot with Deuter's horse-drawn rickety cart which pushes upwards towards the evening sky. Vassilieff's imagery of Joe Deuter obviously inspired some of the younger Australian artists to explore their own culture's mythology. It, however, struggled to communicate with wider Australian audiences. Another case in point is Vassilieff's sculptural work Ned Kelly ${ }^{8}$ REPRODUCTION 6 accompanying his Stenka Razin and executed within the same time frame. The sculpture Ned Kelly was Vassilieff's rendition of an Australian folk hero Ned Kelly, an outlaw, gang leader and murderer (the story of whom, in turn inspired the celebrated Australian painter Sidney Nolan to create his series of works on the same topic). Vassilieff created his Stenka Razin as a symbol of his own existence, while he created his Ned Kelly as a symbol of his Australian cultural environment. The pair of sculptures testify to the artist's attempt to unveil himself to his Australian audiences by comparing the two heroes. Nevertheless, when exhibited together, Ned Kelly resonated with Australian audiences and Stenka Razin still did not. Vassilieff remained as alone as before.

Australian landscape was a natural topic of interest for Vassilieff and he created numerous works in country New South Wales and Victoria. Recognising the world of myth and folk tales in everyday world, he was often depicting ideas rather than the reality as everyone would see it. Vassilieff expressed this thus, as quoted (Sutton 1982: 3) in a catalogue of his posthumous exhibition held in Melbourne in 1982:

Dawn, the sun's rays, grass, flowers, birds, the endless blue pit of the heavens, the steppes and song - all is cemented together, all identify themselves in one huge, heaving impulse in the joy of being alive (Sutton 1982: 3).

Indeed, all of Vassilieff's landscapes transmit the artist's allencompassing view of nature and its forces, with some of these works also containing symbolic figures and motives. Even when painting the landscapes specific to another hemisphere Vassilieff was invoking the vast steppes of his homeland. In the period 1954-1958, he left Stonygrad and lived in rural Victorian towns of Mildura and Swan Hill, in a far flung Melbourne suburb of Eltham and finally back in Mildura. His paintings at the time demonstrate

\footnotetext{
${ }^{7}$ Oil on plywood, $29.5 \times 38.8$, from the collection of Barbara Tucker

${ }^{8}$ Lilydale marble, 30.8 x 29.5 x $10.8 \mathrm{~cm}$, TarraWarra Museum and Art Collection, Victoria
} 
the artist's entirely different take on Australian landscape, now populated with his renditions of odious and vulgar small town mentality inhabitants. Vassilieff's joie de vivre evident in much of his oeuvre was here replaced by the artist's harsh irony and strong sarcasm. Over these last four years of his life, Vassilieff was slowly giving up on attempting to fit into Australian culture within which he lived for over twenty years. His émigré existence was terrifying him to the extent that he was considering abandoning both Australia and his art in the hope of returning to Soviet Union.

\section{Humour}

Vassilieff was seriously considering abandoning Australia on a previous occasion, in 1946, originally for Soviet Union, then for Latin America and finally for South Africa where he was planning to settle for good in early 1947. These plans were abandoned when a young woman answered his advertisement for the sale of Stonygrad. As she was writing him a cheque as a down-payment for the house, Vassilieff reportedly told her that for such a big amount of money she could buy not just the house but himself as well. The young woman soon became his wife (Moore 2012: 91).

As Vassilieff's wife Elizabeth Vassilieff Sutton quoted the artist in the catalogue of his posthumous exhibition in Melbourne in 1982, his artist's credo importantly included a humorous gesture he called by the French term geste:

Your art must not always be deadly serious. It must always have room for the geste and the suggestion (Sutton 1982: 5).

Indeed, Vassilieff's oeuvre overflows with the artist's sweet, refined and often elegant sense of humour. This is especially evident in several of his works executed at different times on the topic of Christian stories and myths. One such example is his painting The Expulsion from Paradise from $1940^{9}$ REPRODUCTION 7 originally a four-segment screen. The left segment of the two central panels shows Adam and Eve and the right segment an archangel. Adam and Eve are represented as strong and young male and female nudes who had just discovered physical love. They are expelled from the luscious Paradise by a warrior angel in a blue drape and red boots blasting

\footnotetext{
${ }^{9}$ Tempera on cotton canvas, four panels, overall app. 167 x $321.4 \mathrm{~cm}$, National Gallery of Australia, Canberra
} 
fire at them. The side panel to the right shows a God like being seated at the golden throne whose features invoke representations of Christ in Byzantine and Russian icon painting tradition. He is surrounded by many creatures and plants of Paradise to which his presence gives life. The side panel to the left shows a large number of human figures and a tall palm tree. Linking all the panels together is the representation of a snake painted on a lower zone across all the panels, its skin patterned in blue and red, its head blue, its eye red. The humour of this image is manifold - Adam and Eve's lust for each other laughs in the face of their expulsion; the warrior angel with his fire hose resembles a firefighter. In the background behind the angel and extending to the panel showing the Christian Lord Vassilieff painted a group of five angels sitting on a fence and engaging in the spectator sport. Another such example is Vassilieff's work Entry into Jerusalem from 1947. ${ }^{10}$ REPRODUCTION 8 Here, the scene of Christ's entry into Jerusalem is not consistent with the Orthodox tradition. A tall male figure with a goatee beard dressed in a suit and top hat surrounded by soldiers and followed by a crowd rides on a donkey. It is night time and this typically Australian small town is asleep. The only symbol linking this scene to the Christian story is a lone palm branch that somebody in the crowd following Christ is waving. Yet another of Vassilieff's irresistibly humorous works on a different topic of Christian story, highly personalised and uniquely Australian, is his painting A prophet among miracles from 1947. ${ }^{11}$ REPRODUCTION 9 The smiling, happy prophet is posing against the backdrop of drought stricken barren Australian landscape, the dark clouds above forming into a mighty storm in the mad heat of a summer afternoon. The prophet had already created a miracle of bringing a water tide to the land - depicted on the left side of the picture plane - soon to engulf the red soil around him and a dead tree-trunk depicted to his left. $\mathrm{He}$ is dressed in gear worn in deserts, in the layers of robes and over robes, and is carrying a fancy parasol in his right hand.

Vassilieff's benevolent humour and geste is evident in many of his works on personalised topics, especially those directly inspired by his cultural memory, and which perhaps could not fully communicate with his Australian audiences. Outside of these works, many other Vassilieff's paintings were deliberately attempting to transmit humour to his Australian peers. This is especially evident in his renditions of street scenes. Among these are A fight I saw from $1941^{12}$ REPRODUCTION 10 which shows a glimpse of the street

\footnotetext{
${ }^{10}$ Canvas, $60.8 \times 73 \mathrm{~cm}$, National Gallery of Australia, Canberra

${ }^{11}$ Composition board, $45.7 \times 60.5 \mathrm{~cm}$, private collection

${ }^{12}$ Canvas, $48 \times 53.2 \mathrm{~cm}$, private collection
} 
fight between two young women, or the works Nudes in Collins Street ${ }^{13}$ REPRODUCTION 11 and Nudes in Bourke Street both from 1943.14 REPRODUCTION 12 Both Collins and Bourke streets are situated in the heart of the city of Melbourne and are the centre of the bustling activity with a continual stream of hundreds of thousands people going to and from their offices and other engagements. The stream of automaton like office workers in Collins Street was later, in 1955, immortalised by the Australian artist John Brack in his painting Collins St, $5 \mathrm{pm}$. The busy life of Bourke Street was previously, in 1886, immortalised by the Australian artist Tom Roberts in his painting Bourke Street (originally titled Allegro con brio). Vassilieff's Collins and Bourke streets of 1943 were populated by busy people shown in the nude, distinguished by their various hats and uniform caps.

\section{Irony as a symbol}

The oeuvre of Danila Vassilieff contains a wealth of allegories and symbols. Some of those again related to his personal experiences, some to his Russian cultural memory, whilst some were meant to communicate with his Australian audiences. A symbol which consistently appears in his art and which contains a universal value is the image of a dog. This image appears in Vassilieff's art since his early Sydney and Melbourne works and is obvious, in many different incarnations, in many of his street scenes of the time. The image takes centre stage in his watercolour series Peter and the Wolf and then reappears in many of his later works including the imagery of Joe Deuter, Entry into Jerusalem and various others. The presence of a dog in Vassilieff's pictorial compositions is nonintrusive and very discreet - the creature is, like the artist himself, an observer of life around him, a wanderer, and an outsider. Although the image of dog in Australian art is a topic of interest to Australian scholars, the extant essay (Astbury 1997) omits to recognise Vassilieff's use of this image. The meaning of the symbol is especially underlined when a history of appearance of dog in Russian culture, art and literature is taken into consideration, from the representations of dog in Russian iconography of the saints Boris and Gleb to Chekhov's Koshtanka, to name just two examples. Vassilieff's inclusion of this symbol of an observing outsider in much of his

\footnotetext{
${ }^{13}$ Plywood, 25.3 x $30.5 \mathrm{~cm}$, National Gallery of Australia, Canberra

${ }^{14}$ Plywood, 25.5 x $31.1 \mathrm{~cm}$, National Gallery of Australia, Canberra
} 
painterly oeuvre is deliberately ironic. The symbol is a depiction of the artist's presence in his works and stands as a representation of his anima.

\section{Sarcasm and grotesque}

Distorted figures, distorted faces he encountered apparently surrounded Vassilieff in the last four years of his life, from 1954 to 1958, in far flung towns of Mildura and Swan Hill in the outback Victoria. Vassilieff rendered the group portraits of the small town dwellers as grotesque and frightening. He painted them at people's weddings, in their home environments, playing with their children and on other occasions. By that time Vassilieff spent over twenty years in Australia and these works can be seen as a testimony to his perspective on Australian society and his relationship with it at the time. Several such works are akin to the work Scream by Edvard Munch from 1893. ${ }^{15}$ However, whilst Munch's grotesquely rendered figure represents pain itself, Vassilieff's grotesque group portraits represent and emanate evil. In observing Munch's work one feels the pain of the character depicted. In observing Vassilieff's works from this late period one feels fear from the depicted characters. These paintings of grotesque can be interpreted as manifestations of Vassilieff's harsh sarcasm. He was alone, surrounded by human caricatures and evil spirits of Australian outback towns. In this period, Vassilieff continued to paint landscapes. Many of those he produced at the time were burdened with the imagery of the lurking spirits taken from the local folklore and myth. Above all, the works from this period reflect the state of the artist's soul. Vassilieff executed a nocturnal painting of a Melbourne street scene A lane in Fitzroy after briefly visiting the city in 1957. It shows a deserted street at night with the spirits of children playing and a dog observing, lit by the mask of the artist. Vassilieff's émigré existence completed a full circle. He could no more attempt to humour his Australian audiences. He could not humour himself. Vassilieff died in 1958 from a heart attack at the home of his friends, art patrons Sunday and John Reed at their estate in Heidi.

A perennial émigré, Vassilieff remained a unique figure in Australian art. However, his immediate legacy can be seen in the works of a young circle of Australian artists whom he befriended while living in Stonygrad. They also gathered at the estate of the art patrons John and Sunday Reed in Heide near

\footnotetext{
${ }^{15}$ Edvard Munch, The Scream, oil, tempera and pastel on cardboard, 1893, National Gallery, Oslo
} 
Melbourne in a circle which included the expressionist painters Charles Blackman, John Perceval, Clifton Pugh, the social realist painter Noel Counihan and Laurence Hope. In works by many of these young artists several flows of Vassilieff's ideas can be traced. Vassilieff's interest in Christian myth became one of the life-long painterly interests of the Australian artist Arthur Boyd (1920 -1999). Vassilieff's giving legitimacy to Russian, and Australian, folklore, would have been one of the sources of inspiration in the oeuvre of Sidney Nolan (1917-1992). Nolan's work at the time included his attempts to represent an Australian folk hero and criminal Ned Kelly through a series of paintings envisaging Kelly's exploits and capture, as well as those envisaging the ill-fated historic expedition of the explorers Burke and Wills. Vassilieff's personal and creative take on life hardships in his work resonated with the Australia painter Albert Tucker (1914-1999). Tucker's expressionistic work during and immediately after the WWII contained the artist's strong comment on the individual and communal physical and moral decline. Vassilieff's provocative treatment of feminine principle in his art is echoed in much of the oeuvre of the Australian painter Joy Hester (1920-1960). These, and several other artists were similarly greatly inspired by Vassilieff's expressionistic idiom.

It is not surprising that Vassilieff's chosen idiom was figurative expressionism. Figurative, because he had an urge to record the physical world as he saw it. And expressionism, because he felt the urge to express his personal feelings and thoughts through his art. Each of Vassilieff's works, both paintings and sculpture, were executed seemingly in a single breath. Representing everyday events, encounters and observations his works always carried visual references to his inner world. Boyd, Nolan, Tucker, Hester and other young artists at the time were equally attracted to this and his expressionistic style and would ask Vassilieff to teach them some of his techniques.

What is the place of Danila Vassilieff within Australian expressionism? Among figurative expressionists in Australian art a special place is held by Vassilieff's contemporary the expressionist painter Ian Fairweather (18911974), a reclusive artist residing in Australia on and off for extended periods of time. Fairweather created a major body of work which can be seen as a blend of figurative and abstract expressionism. His visual language included influences of Indigenous art as well as the arts of several cultures of Asia. This stream in Australian expressionism was taken up by some other artists, such as John Olsen (born 1928), Brett Whiteley (1939-1992) and GW Bot (born 1954), who would combine figurative painting and abstraction within expressionistically rendered landscapes. Expressionism in Australian art 
flourished with advance of abstraction - perhaps the most outstanding abstract expressionist landscape paintings are those by the artists Fred Williams (1927-1982) and Tony Tuckson (1921-1973). It is usually equated with the work of the members of the Sydney 9 group who exhibited together in 1961: Hector Gilliland, Leonard Hessing, the sculptor Clement Meadmore, John Olsen, Carl Plate, Stanislaus Rapotec, William Rose, Eric Smith and Peter Upward. Here the work of Stanislaus Rapotec (1911-1997), a post-WWII émigré painter from Yugoslavia, is especially telling as it is, similarly to Vassilieff's, imbued with the artist's personal feelings, affects and experiences. Although many of these artists had little actual contact with Vassilieff, Vassilieff's art practice paved the way for many Australian artists of these later generations.

A perennial émigré, Vassilieff also remained a unique figure in Russian émigré art. His acclaimed compatriot Mark Chagall (1887-1985), also an émigré, encountered a very different environment in the pre-WWII Europe. Similarly to Vassilieff, Chagall (Alexander 1978) also invoked his cultural memory in many aspects of his oeuvre (Kamensky 2005). Vassilieff's Russian cultural memory was based on Christian Orthodoxy, Chagall's on Judaism and its traditions. Their vastly different life experiences and environments - Vassilieff's in Australia and Chagall's in France, the USA and again in France - are reflected in both the artists' work. During his lifetime, Vassilieff was shunned and neglected. In contrast, Chagall was admired as a great artist which he was. Another Russian émigré expressionistic painter who achieved an important place in art history was the artist of a previous generation Wassily Wassilyevich Kandinsky (1866 1944), one of the pioneers of abstraction in art whose professional career was formed and continued in Germany and then France (Grohmann 1958). It is interesting to note that several of Kandinsky's early works, such as Improvisation 27 (Garden of Love II) from 1912, now in the Metropolitan Museum of Art, his Landscape With Two Poplars also from 1912, now in The Art Institute of Chicago, as well as his Landscape with Factory Chimney from 1910, now in the Solomon R. Guggenheim Museum in the city of New York, resonate with some of Vassilieff's works created decades later. Among the Russian émigré artists of somewhat older generations working in Europe between the two wars with whose work Vassilieff would have been familiar, were Goncharova and Larionov whose life experiences in France, as well as their respective work, again, developed in a vastly different manner from that of Vassilieff.

Outside of his émigré experience, Danila Vassilieff was also a Russian artist. Does Vassilieff's work have a place in Russian expressionism in his 
homeland? Does a perennial émigré have a place in art history of his homeland? Vassilieff's oeuvre can easily be compared to the oeuvre of the father of Russian expressionism in their homeland of Russia, Anatoly Zverev (1931-1986) who introduced his unique form of figurative expressionism to Russian art in the early 1960s. He mostly exhibited in small and underground spaces, never travelled far from Moscow and held his first major solo show shortly before his death. Nevertheless, many of his works invoke Vassilieff's innocent and simple paintings of life around him, especially street scenes, children's portraits and characters from his personal mythology (Opaleva 2014).

Such a comparison between the oeuvre of Vassilieff and that of Zverev provokes a question: would Vassilieff's work be any different were it not for his émigré existence? Vassilieff's inner world laden with his cultural memory resonates with that of Chagall's. Nevertheless his idiom and his stance of an observer and an outsider resonates with that of Zverev. Vassilieff's place in Russian art should be beyond dispute. His place in Australian art today cannot be disputed. Nevertheless his international recognition, unlike that of both Chagall and Zverev, is not yet fulfilled.

Vassilieff's unique idiom was gradually formed before his settling in Australia for the second time. His life experiences as an émigré in isolated and far flung Australia provided for a continual evolution of his work. Vassilieff's work evolved in Australia and is inseparable from his émigré experience. His nostalgia dwelled on his Russian cultural memory. His humour and geste were means to communicate his ideas to his new environment. His sweet irony of being merely an observer of life was the artist's declarative statement. Finally, sarcasm that enveloped the artist over the last four years of his life represented the culmination of his disappointment with his environment. It is hoped that in the future Vassilieff's oeuvre will be examined in light of its place within broader art history.

\section{Bibliography}

Alexander, Sidney.1978. Marc Chagall: A Biography. New York: G.P. Putnam's Sons.

Astbury, Leigh. 1997. The dog in Australian art. In Art and Australia. Vol. 35, no. 2. Sydney: Art ad Australia

Bojic, Zoja. 2007. Imaginary homelands: the art of Danila Vassilieff. Belgrade: Foundation Andrejevic. 
Carroll, Mark (ed.). 2011. The Ballets Russes in Australia and Beyond. Kent Town, SA: Wakefield Press.

Grohmann, Will. 1958. Wassily Kandinsky. Life and Work. New York: Harry N Abrams Inc.

Kamensky, Aleksandr, 2005. Marc Chagall, An Artist From Russia. Moscow: Trilistnik,

Moore, Felicity St John.2012. Vassilieff and his art. South Yarra, Victoria: Macmillan Art Publishing

Opaleva, Natalia. 2014. Anatoly Zverev. Moscow: AZ Museum.

Sutton, Elizabeth. 1982. Father of the Melbourne Expressionist School Danila Vassilieff 1898 - 1958, Quintessential artist and innovator, Watercolours 1940-1955, Mind in creative process, paintings in twentysix series in chronologic order. Melbourne: Niagara Lane Galleries. 


\section{Reproductions of works by Danila Vassilieff}

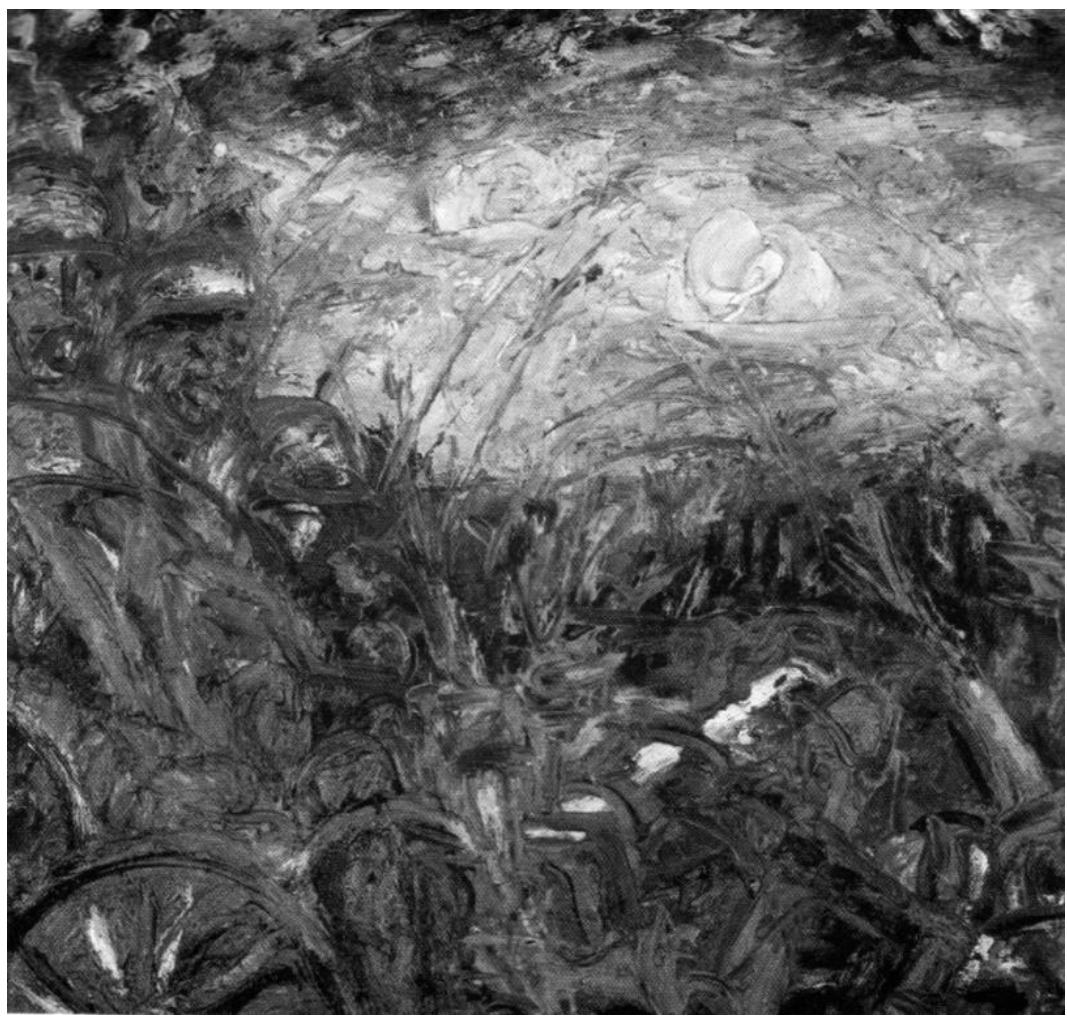

REPRODUCTION 1

Stalingrad, 1945, oil on canvas mounted on board, 49 x $54 \mathrm{~cm}$, private collection 


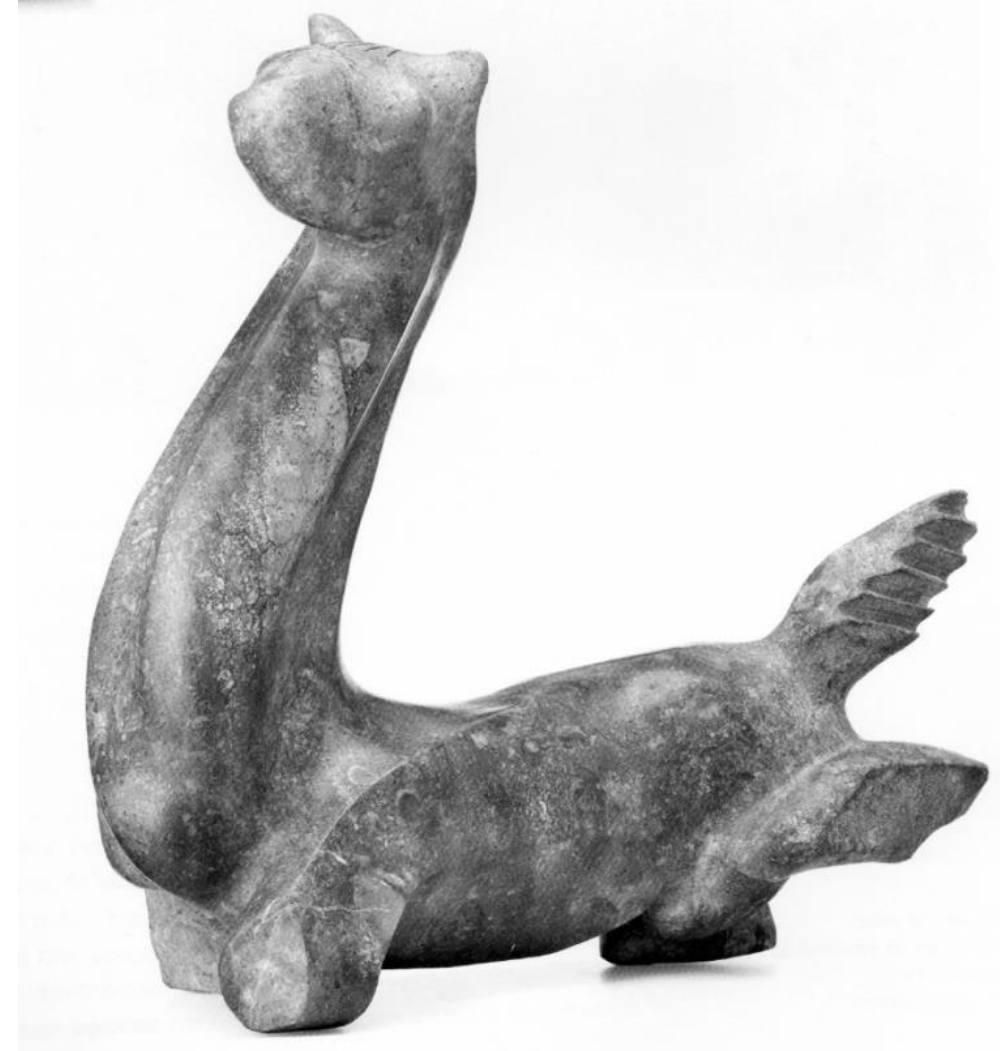

REPRODUCTION 2

Flying horse, 1951, Lilydale marble, 39.5 x 39.5 x $20 \mathrm{~cm}$, Baillieu Myer collection 


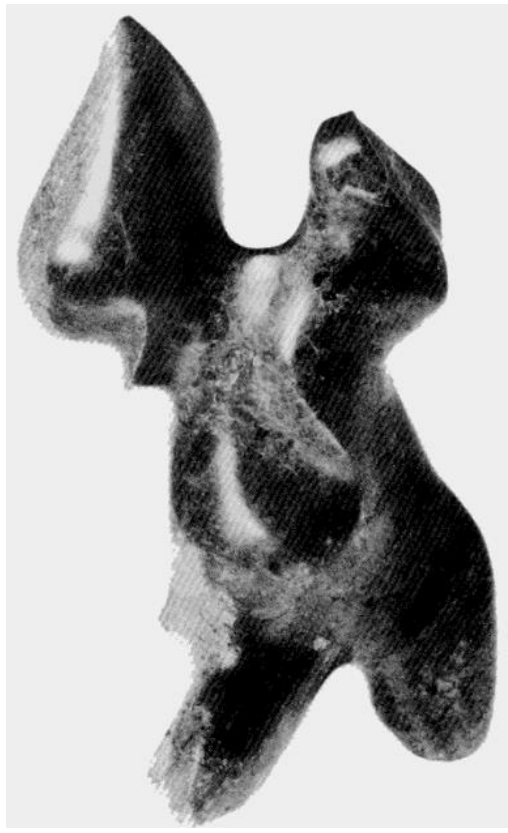

REPRODUCTION 3

Gnome, 1950, Lilydale marble, $27.5 \times 15.2 \times 14 \mathrm{~cm}$ 


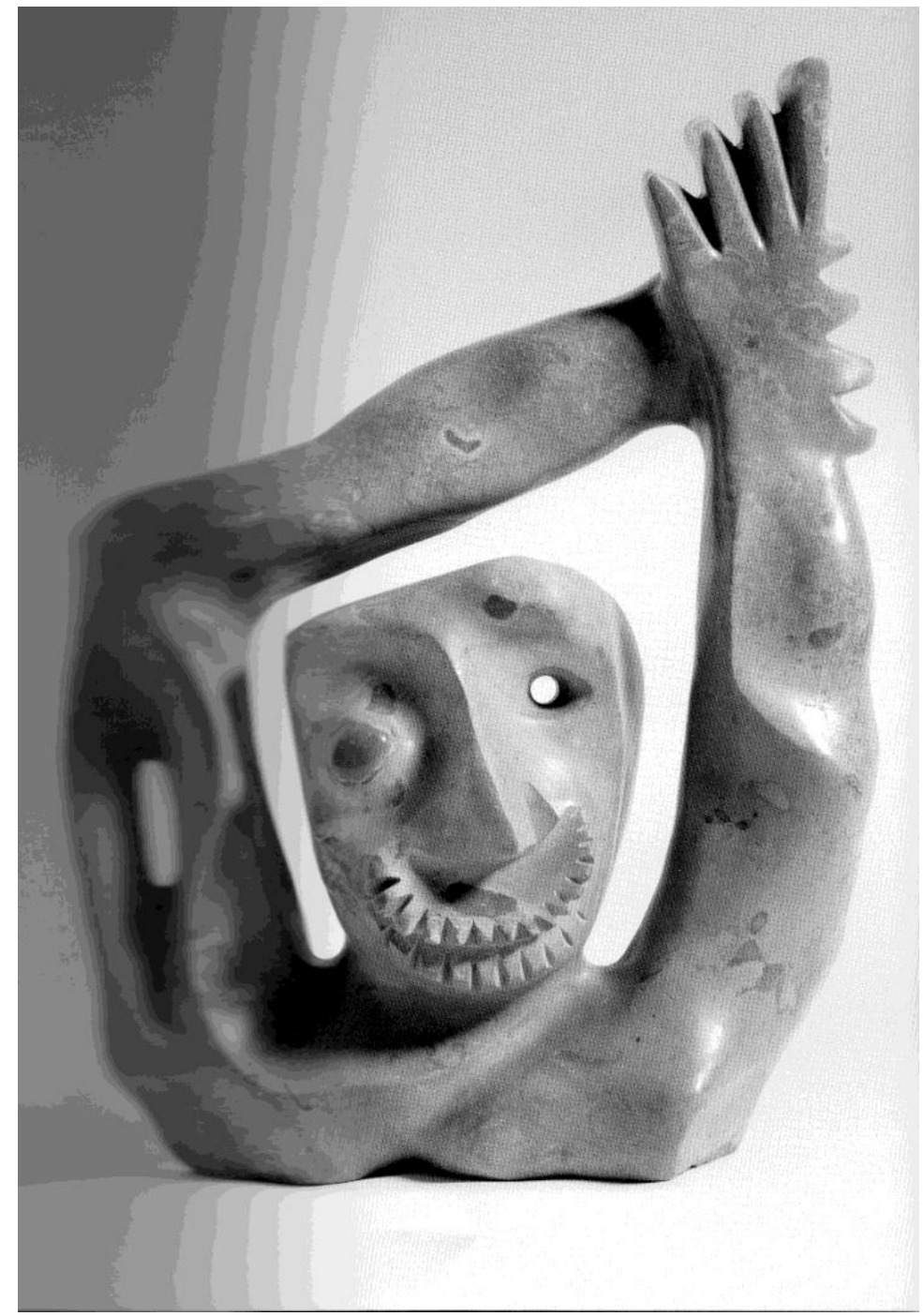

\section{REPRODUCTION 4}

Stenka Razin, 1953, Lilydale marble, 57 x 40 x 13.5 cm, National Gallery of Australia, Canberra 


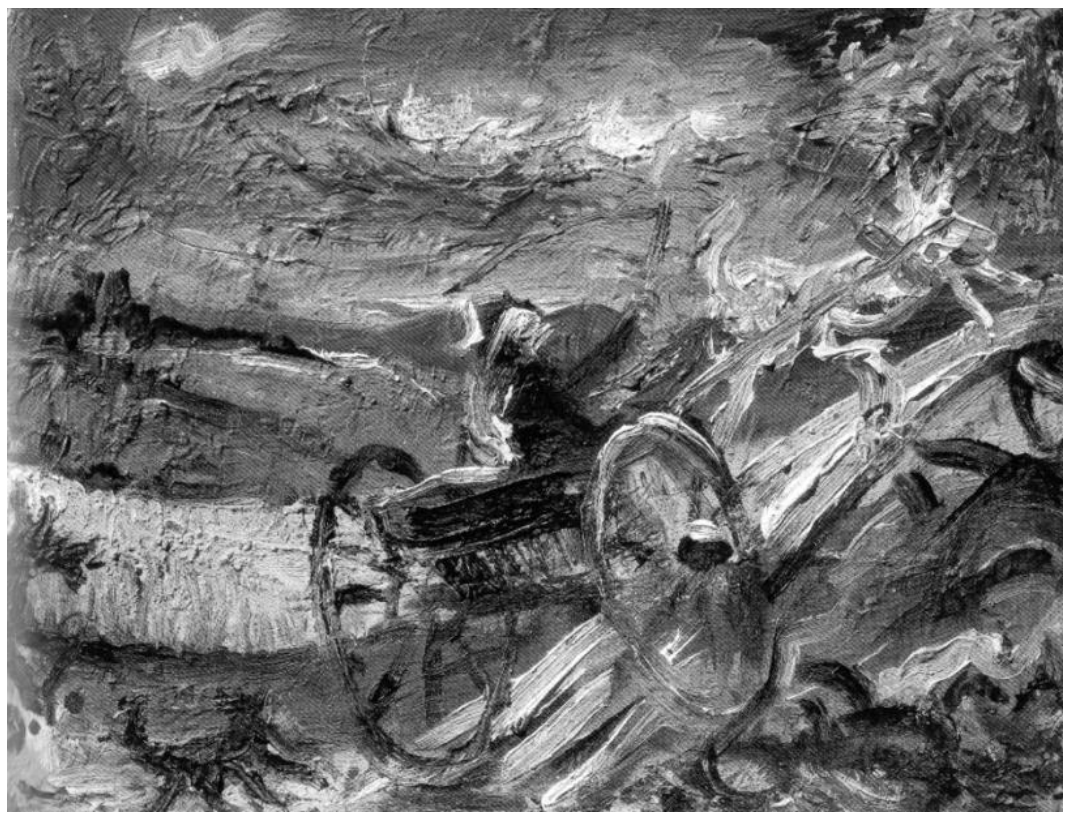

REPRODUCTION 5

Joe Deuter, 1942, oil on plywood, 29.5 x 38.8, from the collection of Barbara Tucker 


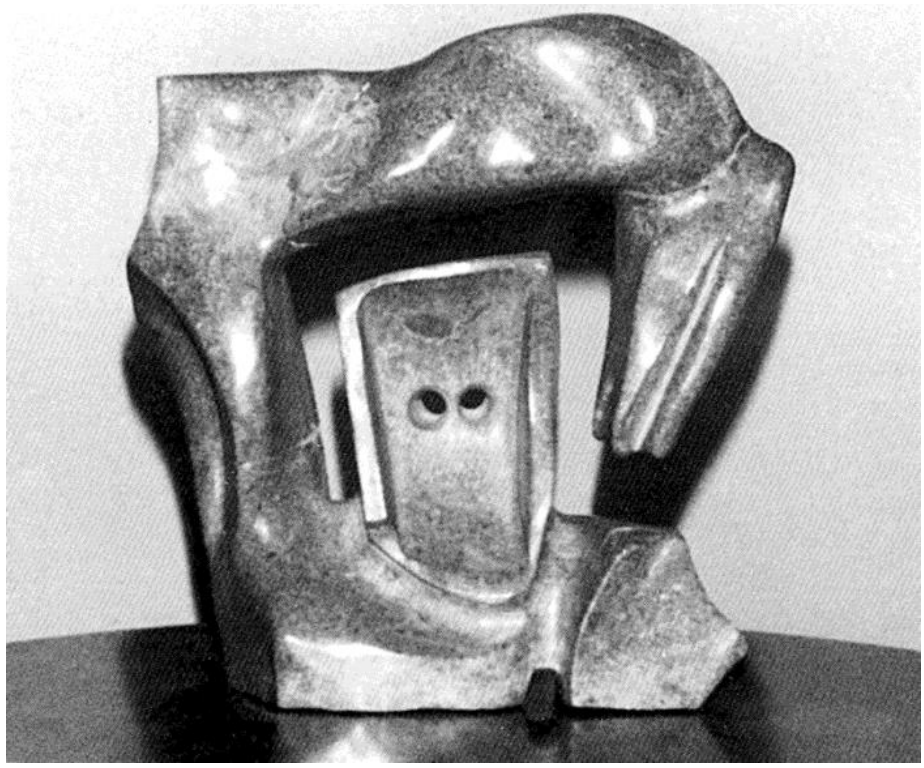

REPRODUCTION 6

Ned Kelly, 1953, Lilydale marble, 30.8 x 29.5 x $10.8 \mathrm{~cm}$, TarraWarra Museum and Art Collection, Victoria 


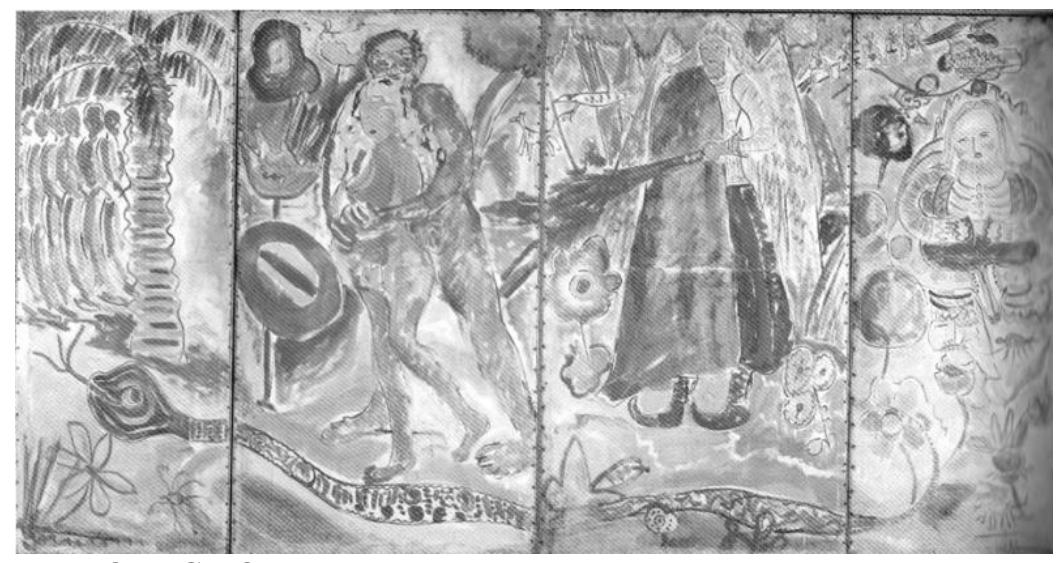

REPRODUCTION 7

Expulsion from Paradise, 1940, tempera on cotton canvas, four panels, overall app. 167 x $321.4 \mathrm{~cm}$, National Gallery of Australia, Canberra 


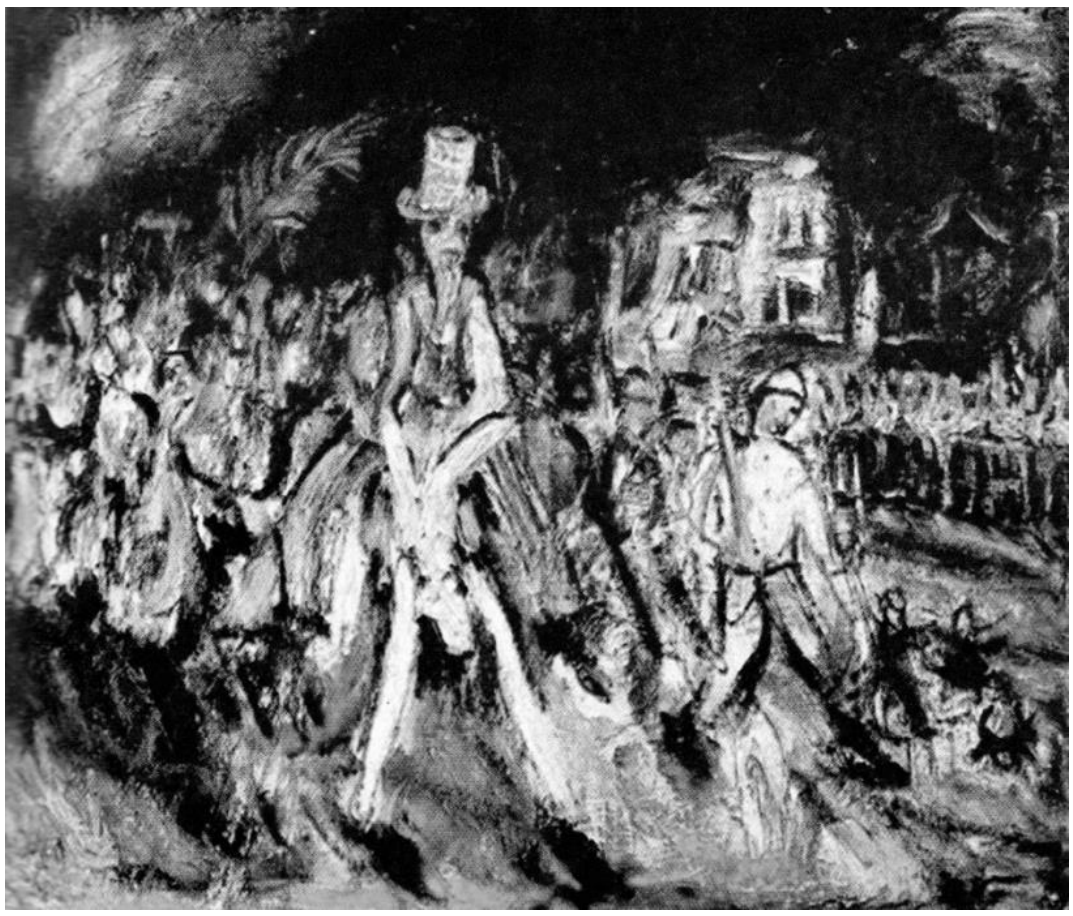

REPRODUCTION 8

Entry into Jerusalem, 1947, canvas, 60.8 x $73 \mathrm{~cm}$, National Gallery of Australia, Canberra 


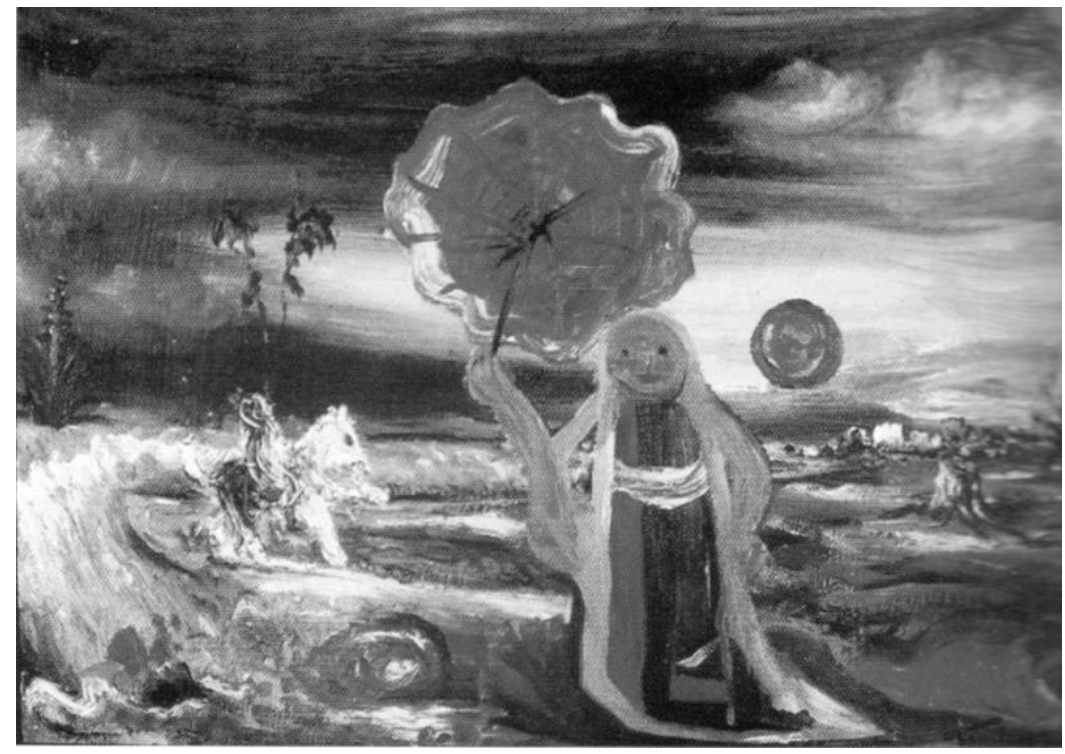

REPRODUCTION 9

A prophet among miracles, 1947, composition board, 45.7 x $60.5 \mathrm{~cm}$, private collection 


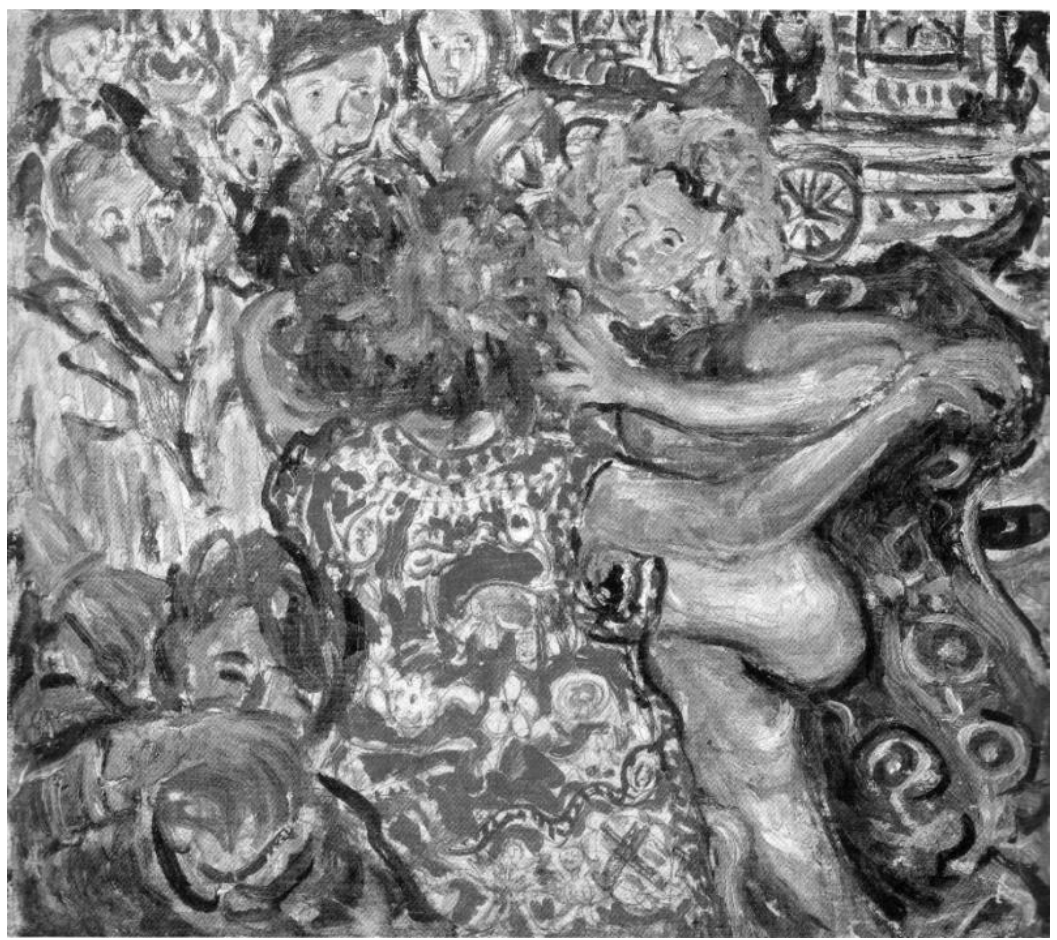

REPRODUCTION 10

A fight I saw, 1941, canvas, 48 x $53.2 \mathrm{~cm}$, private collection 


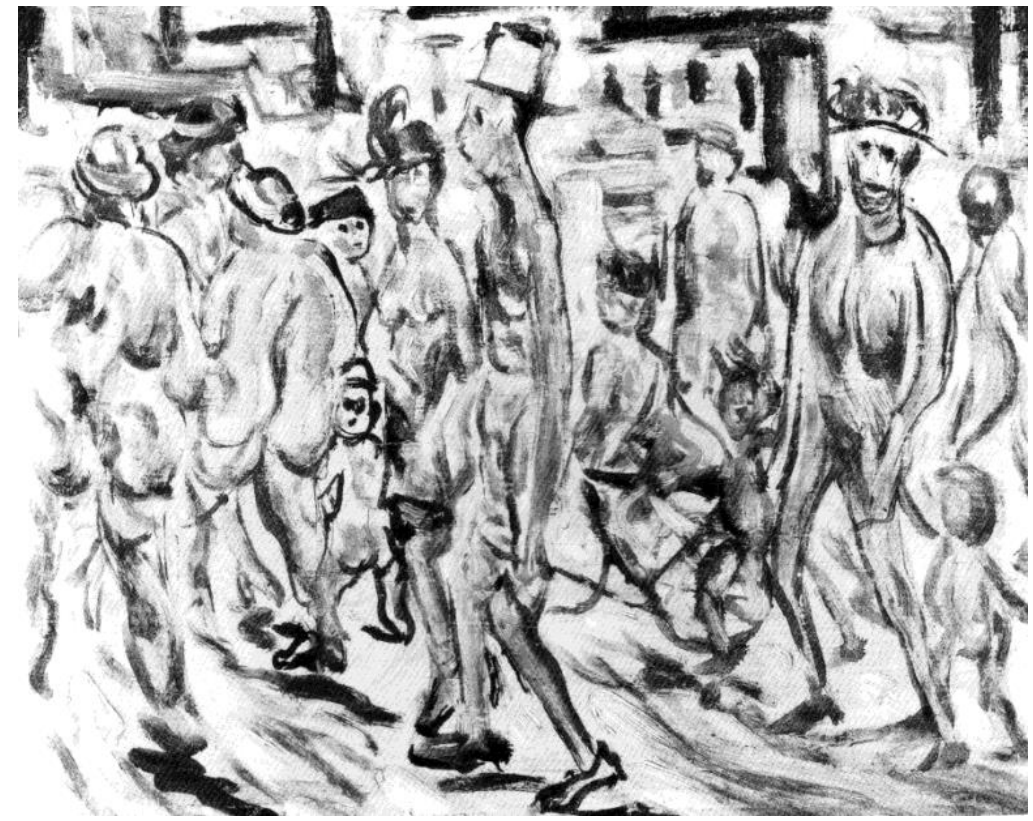

REPRODUCTION 11

Nudes in Collins Street , 1943, plywood, 25.3 x 30.5 cm, National Gallery of Australia, Canberra 


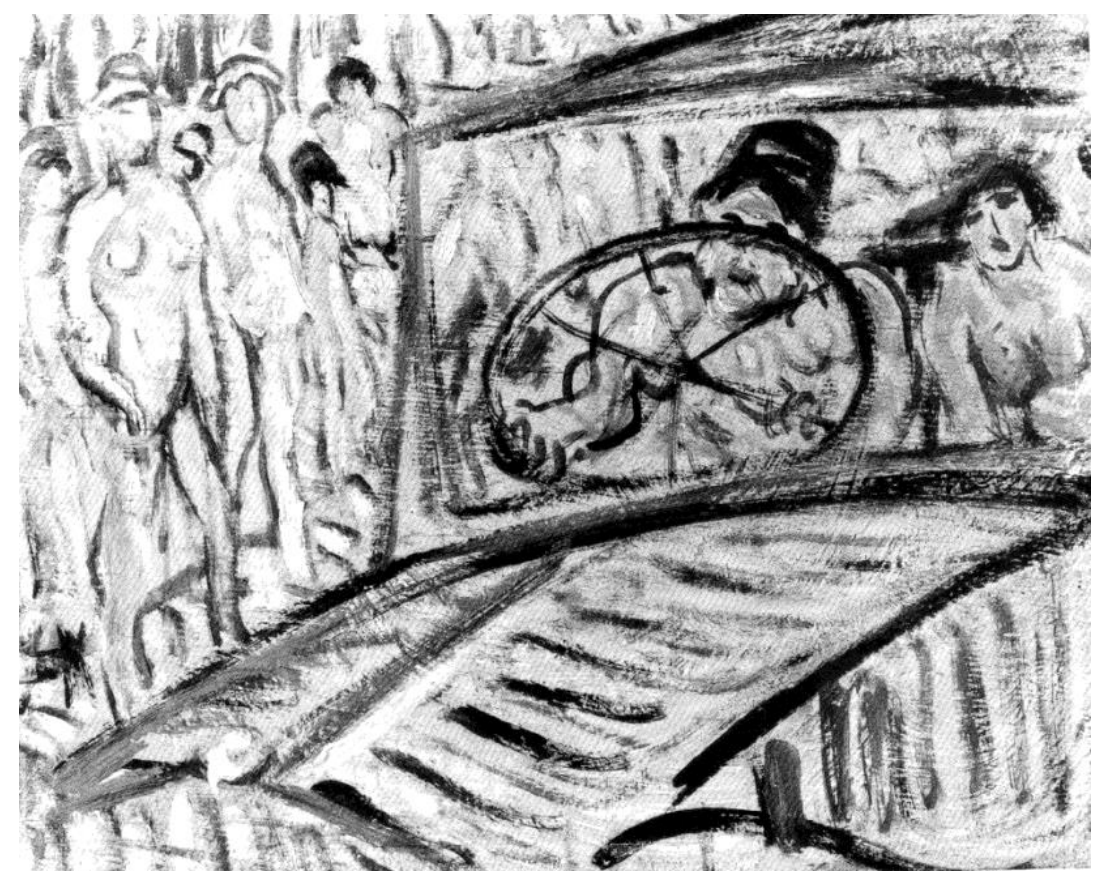

REPRODUCTION 12

Nudes in Bourke Street, 1943, plywood, 25.5 x $31.1 \mathrm{~cm}$, National Gallery of Australia, Canberra 